\title{
Gangguan fisiologi dan biokimia Crocidolomia pavonana (F.) (Lepidoptera: Crambidae) akibat perlakuan ekstrak campuran Tephrosia vogelli dan Piper aduncum
}

\author{
Physiological and biochemical interferences caused by treatment of \\ mixture extracts of Tephrosia vogelli and Piper aduncum
}

\author{
Eka Candra Lina ${ }^{1,2^{*}}$, Dadang ${ }^{2}$, Syafrida Manuwoto ${ }^{2}$, Gustini Syahbirin ${ }^{3}$ \\ 'Jurusan Agroteknologi, Fakultas Pertanian, Universitas Andalas \\ Kampus Unand Limau Manis, Padang 25163 \\ ${ }^{2}$ Departemen Proteksi Tanaman, Fakultas Pertanian, Institut Pertanian Bogor \\ Jalan Kamper, Kampus IPB Dramaga, Bogor 16680 \\ ${ }^{3}$ Departemen Kimia, Fakultas MIPA, Institut Pertanian Bogor \\ Gedung Fapet Wing 2 Lt 4, Kampus IPB Dramaga, Bogor 16680
}

(diterima September 2014, disetujui Mei 2015)

\begin{abstract}
Ekstrak tanaman dapat mempengaruhi fisiologi dan biokimia serangga yang meliputi penghambatan makan, asimilasi makanan, dan dan aktivitas enzim detoksifikasi, yaitu sitokrom b5 dan sitokrom P450. Penelitian ini bertujuan untuk menguji pengaruh ekstrak campuran Tephrosia vogelii : Piper aduncum $(1: 5)$ terhadap fisiologi Crocidolomia pavonana (F.) dan pengaruh ekstrak $P$. aduncum terhadap biokimia C. pavonana. Pengujian ekstrak campuran T. vogelii : P. aduncum (1:5) pada konsentrasi $0,06 \%$ atau setara dengan $\mathrm{LC}_{95}$ menghambat makan larva $C$. pavonana hingga $94,82 \%$. Ekstrak campuran yang diuji pada $\mathrm{LC}_{25}(0,007 \%)$ dan $\mathrm{LC}_{50}(0,014 \%)$ menyebabkan gangguan pertumbuhan relatif larva C. pavonana. Gangguan ini disebabkan oleh toksisitas intrinsik ekstrak campuran yang masuk ke dalam tubuh serangga. Selain gangguan pada pertumbuhan larva uji, juga terjadi peningkatan daya cerna serangga sebesar $11,11 \%$ sebagai bentuk adaptasi terhadap senyawa toksik tumbuhan. Adaptasi lain yang dilakukan larva C. pavonana adalah mekanisme detoksifikasi terhadap ekstrak $P$. aduncum. Hal ini tampak dari peningkatan aktivitas enzim oksidasi sitokrom b5 dan sitokrom P450 pada perlakuan in vivo dan in vitro jika dibandingkan dengan kontrol. Penelitian ini memberikan informasi mengenai cara kerja ekstrak campuran $T$. vogelii : P. aduncum $(1: 5)$ pada larva $C$. pavonana dan mekanisme detoksifikasi larva terhadap ekstrak $P$. aduncum.
\end{abstract}

Key words: antifeedant, asimilasi, enzim, oksidasi, sitokrom

\begin{abstract}
ABSTRAK
Plant extracts have been known to cause physiological and biochemical interferences against insect, such as feeding inhibitor, food assimilation, and changes on activity of cytochrome b5 and cytochrome P450. This study was carried out to examine the effect of the extracts mixture of Tephrosia vogeliiand: Piper aduncum $(1: 5)$ on the physiology of Crocidolomia pavonana (F.) as well as extract of $P$. aduncum on biochemical of $C$. pavonana. The study showed that larvae of $C$. pavonana was experiencing a feeding inhibition until $94.82 \%$ after treated with extracts mixture on concentration $0.06 \%$ or equivalent to $\mathrm{LC}_{95}$. However, larvae treated with extracts mixture on $\mathrm{LC}_{25}$
\end{abstract}

\footnotetext{
*Penulis korespondensi: Eka Candra Lina, Universitas Andalas Padang, Fakultas Pertanian, Jurusan Agroteknologi, Kampus Unand Limau Manis, Padang 25163

Tel: 0813-82568905, Email: trijata1012@yahoo.com 
and $\mathrm{LC}_{50}$ only experienced a relative growth disorders as a result of intrinsic toxicity of extracts mixture which enters into the body of insects. Insect adaptation to toxic plant compounds indicated by an increase in the digestibility of larvae approximately $11.11 \%$. Furthermore, detoxification mechanism by larvae against active compounds of $P$. aduncum occured and shown by an increase of oxidative enzyme activity of cytochrome b5 and cytochrome P450, in in vivo and in vitro compared to control. This study provides an information about mode of action of extracts mixture of T. vogelii and $P$. aduncum $(1: 5)$ on larvae of $C$. pavonana and detoxification mechanism by larvae due to extract of $P$. aduncum

Kata kunci: antifeedant, assimilation, cytochrome, enzyme, oxidation

\section{PENDAHULUAN}

Keberadaan metabolit primer dan metabolit sekunder tanaman menjadi penentu dalam interaksi serangga dengan tanaman inangnya (Fraenkel 1969; Schoonhoven 2005). Nutrisi berupa protein, karbohidrat dan lemak sangat mempengaruhi kebugaran serangga dan keturunannya, sebaliknya keberadaan metabolit sekunder tanaman secara langsung dan tidak langsung menjadi pembatas bagi kehidupan serangga (Schoonhoven 2005). Metabolit sekunder tanaman dapat menghambat makan (antifeedant), menyebabkan kematian, menghambat peneluran, mengganggu aktivitas pengaturan pertumbuhan, dan menghambat reproduksi.

Kesesuaian tanaman sebagai sumber makanan dapat diketahui dengan melakukan uji asimilasi makanan oleh serangga, yang dihitung berdasarkan metode gravimetri (Waldbauer 1968). Keberadaan senyawa asing pada makanan menyebabkan serangga meninggalkan tanaman tersebut atau beradaptasi. Bentuk adaptasi yang dilakukan serangga antara lain melakukan detoksifikasi senyawa alelokimia tanaman melalui degradasi secara enzimatik. Enzim yang paling sering dipelajari dan efektif memetabolisme toksikan adalah sitokrom P450-monooksigenase disebut juga polisubstrat monooksigenase (PSMOs) atau mixed-function oxidase (MFO) (Dauterman \& Hodgson 1978).

Beberapa tanaman yang diketahui memiliki dampak negatif bagi serangga adalah Piper aduncum (Piperaceae) dan Tephrosia vogelii (Leguminosae). Daun T. vogelii diketahui mengandung senyawa kelompok isoflavonoid seperti rotenon dan senyawa rotenoid lain yang bersifat insektisida, yaitu deguelin dan tefrosin (Delfel et al. 1970; Gaskins et al. 1972; Lambert et al. 1993). Tumbuhan famili Piperaceae selain bersifat toksik diketahui memiliki sifat sinergis. Senyawa lignan yang mengandung gugus metilendioksifenil dapat menghambat aktivitas enzim sitokrom P450 (Metcalf 1967; Bernard et al. 1989). Menurut Bernard et al. (1990), dilapiol yang berasal dari P. aduncum dapat menghambat aktivitas enzim sitokrom P450 dalam sediaan mikrosom dari selsel saluran pencernaan larva penggerek batang jagung Ostrinia nubilalis (Hübner). Sifat sinergis ini sangat menguntungkan untuk pengembangan insektisida nabati campuran sebagai alternatif pengendalian di masa yang akan datang. Penelitian ini bertujuan untuk melihat pengaruh ekstrak $T$. vogelii dan $P$. aduncum terhadap fisiologi dan biokimia Crocidolomia pavonana (Fabricius).

\section{BAHAN DAN METODE}

\section{Tempat dan waktu penelitian}

Penelitian ini dilaksanakan di Laboratorium Fisiologi dan Toksikologi Serangga, Departemen Proteksi Tanaman, Fakultas Pertanian, Institut Pertanian Bogor (IPB), dan Laboratorium Penelitian dan Pelayanan Kimia, Universitas Padjajaran, Bandung, pada bulan Maret 2013 sampai September 2013.

\section{Ekstraksi dan pencampuran ekstrak}

Ekstraksi $P$. aduncum, dan T. vogelii dilakukan dengan metode perendaman/maserasi menggunakan pelarut etil asetat. Pemilihan pelarut berdasarkan penelitian sebelumnya dan studi literatur. mengacu pada penelitian ekstrak kasar yang dilakukan oleh Abizar \& Prijono (2010); Nailufar (2011); Lago et al. (2009); dan Flores et al. (2009). Sifat aktivitas campuran dianalisis berdasarkan model kerja bersama berbeda dengan menghitung indeks kombinasi pada taraf $\mathrm{LC}_{50}$ dan $\mathrm{LC}_{95}$. Indeks kombinasi (IK) pada taraf $\mathrm{LC}_{\mathrm{x}}$ 
tersebut dihitung dengan rumus Chou \& Talalay (1984). Campuran yang memiliki nilai IK paling kecil digunakan dalam pengujian penghambat makan dan asimilasi makanan.

\section{Destilasi buah $P$. aduncum}

P. aduncum yang diperoleh dari areal kampus IPB disiapkan sebanyak $500 \mathrm{~g}$ kemudian didestilasi selama dua jam sejak air di dalam labu mendidih. Minyak yang menetes pada kolom penampung kemudian dipindahkan secara perlahan ke dalam botol kaca. Magnesium sulfat digunakan untuk menghilangkan air yang tersisa di dalam cairan ekstrak yang diperoleh. Ekstrak hasil destilasi digunakan dalam perlakuan analisis enzim sitokrom P450 dan sitokrom b5 larva C. pavonana.

Percobaan pengaruh ekstrak campuran $T$. vogelii : $P$. aduncum $(1: 5)$ terhadap aktivitas penghambat makan larva $C$. pavonana

Aktivitas penghambat makan ekstrak campuran diuji terhadap C. pavonana dengan metode residu pada daun tanpa pilihan. Dua lembar daun perlakuan dan kontrol dimasukkan ke dalam cawan petri terpisah yang sudah dialasi tisu. Lima belas ekor larva $C$. pavonana instar 2 dimasukkan ke dalam cawan petri dan dibiarkan makan daun percobaan selama $24 \mathrm{jam}$. Luas daun yang dimakan langsung dipetakan di atas kertas milimeter untuk dihitung jumlah luas daun yang dimakan. Percobaan disusun dalam rancangan acak lengkap dengan lima perlakuan dan lima ulangan ditambah kontrol. Pengaruh penghambatan makan tanpa pilihan (PM) dihitung dengan rumus:

$$
\mathrm{PM}=[1-(\mathrm{Lp} / \mathrm{Lk})] \times 100 \% \text {, dengan }
$$

Lk: luas daun kontrol yang dimakan; Lp: luas daun perlakuan yang dimakan.

Perbedaan antara luas daun perlakuan dan luas daun kontrol yang dimakan dianalisis dengan sidik ragam yang dilanjutkan dengan uji selang berganda Duncan pada taraf nyata 5\% (Steel et al. 1997).

Percobaan pengaruh ekstrak campuran T. vogelii : P. aduncum $(1: 5)$ terhadap asimilasi makanan larva $C$. pavonana

Pengaruh ekstrak campuran $T$. vogelii : $P$. aduncum (1 : 5) terhadap efisiensi asimilasi makanan larva C. pavonana instar ke-3 diuji pada konsentrasi $\mathrm{LC}_{25}$ dan $\mathrm{LC}_{50}$. Larva yang digunakan dalam percobaan ditimbang satu per satu, kemudian dimasukkan ke dalam cawan petri yang di dalamnya telah berisi daun perlakuan $(4 \mathrm{~cm} \mathrm{x}$ $4 \mathrm{~cm}$ ) yang telah diketahui bobotnya. Perlakuan ini menggunakan 15 ekor larva C. pavonana instar ke-3. Pengamatan dilakukan 48 jam setelah perlakuan, kemudian larva uji, pakan yang tersisa, dan fesesnya dikeringkan di dalam oven secara terpisah pada suhu $100{ }^{\circ} \mathrm{C}$ sampai bobotnya konstan. Untuk memperkirakan bobot kering awal, 10 larva dan 10 daun contoh (dengan ukuran yang sama seperti yang digunakan dalam perlakuan) ditimbang secara terpisah kemudian langsung dikeringkan sampai bobotnya konstan dan ditimbang lagi. Perbandingan bobot larva atau pakan sesudah dan sebelum pengeringan merupakan proporsi bobot kering terhadap bobot basah.

Bobot kering $(\mathrm{BK})=$ bobot basah $\mathrm{x} \frac{\mathrm{BK} \text { contoh }}{\mathrm{BB} \text { contoh }}$

Data yang diperoleh digunakan untuk menentukan nilai parameter efisiensi pemanfaatan makanan. Parameter yang diukur dalam percobaan ini ialah laju konsumsi (LK), laju konsumsi relatif (LKR), laju pertumbuhan (LP), laju pertumbuhan relatif (LPR), daya cerna (DC), efisiensi konversi makanan dikonsumsi (EMK), dan efisiensi konversi makanan dicerna (EMC), yang dihitung berdasarkan gravimetrik (Waldbauer 1968). Data setiap parameter tersebut diolah dengan sidik ragam dan pembandingan nilai tengah antardosis dilakukan dengan uji Duncan pada taraf nyata 5\% (Steel et al. 1997).

\section{Percobaan pengaruh ekstrak $P$. aduncum terhadap aktivitas enzim detoksifikasi sitokrom b5 dan sitokrom $\mathbf{P 4 5 0}$}

Analisis enzim sitokrom P450 dan sitokrom b5 dilakukan secara in vivo dan in vitro. Pengujian secara in vivo diawali dengan memberi larva $C$. pavonana instar 3 perlakuan ekstrak hasil destilasi P. aduncum $0,24 \%\left(\mathrm{LC}_{50}\right)$ dengan metode residu pada daun. Larva dibiarkan memakan daun perlakuan selama dua hari, setelah ganti kulit menjadi instar 4 larva kemudian dibedah dan diambil saluran pencernaan bagian tengah sebagai sumber enzim (Kranthi 2005). Pada pengujian in vitro sebanyak $100 \mu 1$ minyak $P$. aduncum hasil destilasi 
yang telah diencerkan dengan buffer sebanyak 100 kali dimasukkan ke dalam kuvet yang berisi enzim. Prosedur lainnya tidak berbeda dengan perlakuan in vivo seperti metode yang dikemukakan oleh Omura \& Sato (1964) dan Kranthi (2005).

Data hasil pengukuran sampel pada absorbansi (ABS) tertentu menggunakan spektrofotometer digunakan untuk menghitung aktivitas sitokrom b5 dan sitokrom $\mathrm{P} 450$ per mg protein dengan rumus yang dikemukakan oleh Kranthi (2005) berikut ini.

Sitokrom b5 (ABS pada 424-ABS pada 409) x 1000 $(\mu \mathrm{M})$ 184

Sitokrom 450 (ABS pada 450 - ABS pada 490) x 1000 $(\mu \mathrm{M})$ 91

\section{HASIL}

Pengaruh ekstrak campuran $T$. vogelii : $P$. aduncum $(1: 5)$ terhadap aktivitas penghambat makan larva $C$. pavonana

Hasil pengujian ekstrak campuran $T$. vogelii : P. aduncum (1: 5) menunjukkan persentase penghambatan makan yang semakin meningkat dengan meningkatnya konsentrasi ekstrak yang diaplikasikan. Penghambatan pada konsentrasi $0,004 \%$ mencapai $16,21 \%$. Pada dua konsentrasi tertinggi, yaitu $0,03 \%$ dan $0,06 \%$, penghambatan makan yang terjadi mencapai $72,07 \%$ dan $94,82 \%$ (Tabel 1). Laju pertumbuhan larva uji tidak berbeda nyata dengan kontrol sedangkan laju pertumbuhan relatif larva perlakuan mengalami penurunan yang signifikan (Tabel 2).

Pengaruh ekstrak campuran $T$. vogelii : $P$. aduncum $(1: 5)$ terhadap asimilasi makanan larva $C$. pavonana

Hasil pengujian efisiensi makanan oleh larva $C$. pavonana yang diberi perlakuan ekstrak campuran T. vogelii : P. aduncum $(1: 5)$ tampak pada Tabel 2. Laju konsumsi dan laju konsumsi relatif" larva C. pavonana yang diberi perlakuan tidak berbeda nyata dengan kontrol. Larva uji memakan daun perlakuan seperti biasa tanpa terganggu oleh adanya komponen aktif yang berasal dari $T$. vogelii dan $P$. aduncum. Hal ini konsisten dengan pengujian efek antifeedant, yaitu efek penghambatan tidak terjadi pada konsentrasi rendah. Pada konsentrasi 0,007\% atau setara $\mathrm{LC}_{25}$ laju konsumsi sebesar $0,005 \mathrm{mg} /$ hari, begitu juga pada konsentrasi $0,014 \%$ yang setara $\mathrm{LC}_{50}$ laju konsumsi tidak berkurang tetap sebesar $0,005 \mathrm{mg} / \mathrm{hari}$.

Tabel 1. Efek antifeedant ekstrak campuran Tephrosia vogelii : Piper aduncum (1:5) terhadap Crocidolomia pavonana

\begin{tabular}{lcc}
\hline Perlakuan (\%) & Daun dikonsumsi (\%)* & Penghambatan (\%)* \\
\hline Kontrol (0) & $8,88 \mathrm{a}$ & - \\
C5 $(0,004)$ & $7,44 \mathrm{ab}$ & $16,21 \mathrm{ab}$ \\
C4 $(0,008)$ & $6,55 \mathrm{ab}$ & $26,24 \mathrm{ab}$ \\
C3 $(0,015)$ & $5,91 \mathrm{~b}$ & $33,45 \mathrm{~b}$ \\
C2 $(0,030)$ & $2,48 \mathrm{c}$ & $72,07 \mathrm{c}$ \\
C1 $(0,060)$ & $0,46 \mathrm{c}$ & $94,82 \mathrm{c}$ \\
\hline
\end{tabular}

*Angka selajur yang diikuti huruf yang sama tidak berbeda nyata (uji Duncan, $\alpha=0,05$ ).

Tabel 2. Pengaruh ekstrak campuran Tephrosia vogelii : Piper aduncum (1:5) terhadap indeks efisiensi pemanfaatan makanan larva Crocidolomia pavonana

\begin{tabular}{lcccrrrr}
\hline Konsentrasi (\%) & \multicolumn{2}{c}{$\begin{array}{c}\text { Laju konsumsi } \\
(\mathrm{mg} / \text { hari)* }\end{array}$} & \multicolumn{2}{c}{$\begin{array}{c}\text { Laju pertumbuhan } \\
(\mathrm{mg} / \text { hari)* }\end{array}$} & \multicolumn{3}{c}{$\begin{array}{c}\text { Efisiensi pemanfaatan makanan } \\
(\%)^{*}\end{array}$} \\
\hline & $\mathrm{LK}$ & $\mathrm{LKR}$ & $\mathrm{LP}$ & $\mathrm{LPR}$ & $\mathrm{DC}$ & $\mathrm{EMK}$ & $\mathrm{EMC}$ \\
Kontrol & $0,008 \mathrm{a}$ & $1,49 \mathrm{a}$ & $0,0022 \mathrm{a}$ & $0,421 \mathrm{a}$ & $0,008 \mathrm{a}$ & $8,65 \mathrm{a}$ & $11,02 \mathrm{a}$ \\
$0,007 / \mathrm{LC}_{25}$ & $0,005 \mathrm{a}$ & $1,33 \mathrm{a}$ & $0,0019 \mathrm{a}$ & $0,390 \mathrm{~b}$ & $0,009 \mathrm{~b}$ & $10,37 \mathrm{a}$ & $10,78 \mathrm{a}$ \\
$0,014 / \mathrm{LC}_{50}$ & $0,005 \mathrm{a}$ & $1,22 \mathrm{a}$ & $0,0016 \mathrm{a}$ & $0,399 \mathrm{~b}$ & $0,009 \mathrm{~b}$ & $4,13 \mathrm{a}$ & $4,61 \mathrm{a}$ \\
\hline
\end{tabular}

*Angka selajur yang diikuti dengan huruf yang sama tidak berbeda nyata (uji Duncan, $\alpha=0,05$ ). 
Pengaruh ekstrak $P$. aduncum terhadap aktivitas enzim detoksifikasi sitokrom b5 dan sitokrom P450

Hasil analisis enzim secara keseluruhan dapat dilihat pada Tabel 3. Aktivitas spesifik sitokrom b5 pada perlakuan in vitro memberikan hasil paling tinggi, yaitu sebesar $0,931 \mathrm{nmol} / \mathrm{mg}$ protein, kemudian diikuti oleh perlakuan in vivo dan yang terakhir kontrol dengan nilai berturutturut 0,378 dan $0,047 \mathrm{nmol} / \mathrm{mg}$ protein. Pola yang sama juga tampak pada sitokrom P450, aktivitas spesifik sampel pada perlakuan in vitro memiliki nilai tertinggi, yaitu $0,736 \mathrm{nmol} / \mathrm{mg}$ protein. Nilai perlakuan in vivo sebesar $0,347 \mathrm{nmol} / \mathrm{mg}$ protein dan kontrol 0,238 nmol/mg protein.

Pada pengujian ini sifat bahan aktif utama P. aduncum, yaitu dilapiol, sebagai penghambat enzim polisubstrat monooksigenase (PSMO) atau sitokrom b5 dan sitokrom P450 tidak tampak dengan nyata (Tabel 3). Pada kontrol aktivitas sitokrom P450 lebih rendah dibandingkan dengan perlakuan in vitro dan in vivo. Efek sinergis tampak nyata jika pada perlakuan in vivo dan in vitro aktivitas sitokrom P450 lebih rendah dibandingkan dengan kontrol.

\section{PEMBAHASAN}

Ekstrak campuran T. vogelii : $P$. aduncum (1 : 5) memiliki efek antifeedant. Efek antifeedant ini ikut menyumbang terhadap kematian serangga uji C. pavonana. Jika dibandingkan dengan kontrol, persen daun perlakuan yang dikonsumsi menurun secara signifikan. Serangga tetap mengkonsumsi daun yang diberi perlakuan ekstrak campuran meskipun sangat sedikit terutama pada konsentrasi tinggi. Perilaku makan daun beperlakuan kemudian berhenti setelah makan beberapa saat menunjukkan efek antifeedant sekunder. Miller \& Stricler (1984) menjelaskan bahwa sifat toksik senyawa tanaman terhadap serangga dapat berupa gangguan terhadap perkembangan serangga secara langsung (intrinsik) maupun tidak langsung (ekstrinsik). Efek antifeedant yang dikandung tanaman dapat dideteksi serangga melalui sistem indera (efek antifeedant primer), atau mempengaruhi syaraf pusat serangga yang mengatur proses makan (efek antifeedant sekunder). Penghambatan makan ekstrak campuran ini berasal dari ekstrak $P$. aduncum dan $T$. vogelii secara tunggal. Pada penelitian sebelumnya Scott et al. (2004) menjelaskan bahwa senyawa sekunder yang berasal dari spesies Piperaceae bersifat antifeedant terhadap serangga. Morallo-Rejesus (1986) juga melaporkan bahwa ekstrak daun $T$. vogelii bersifat insektisida, antifeedant, dan repellent, terhadap larva Plutella xylostella (Linnaeus). Begitu juga penelitian Wulan (2008) menunjukkan fraksi n-heksana daun $T$. vogelii juga memiliki efek antifeedant (penghambat makan) terhadap larva $C$. pavonana instar ke-2 sebesar 32,7-79,6\%. Abizar \& Prijono (2010) menjelaskan ekstrak T. vogelii bunga ungu menghambat makan $C$. pavonana sehingga menghambat perkembangan larva $C$. pavonana.

Pada konsentrasi rendah efek penghambatan makan larva $C$. pavonana tidak berbeda jika dibandingkan dengan kontrol. Hal ini karena ekstrak campuran $T$. vogelii : $P$. aduncum (1:5) tidak memiliki sifat antifeedant primer, dan pada konsentrasi rendah jumlah bahan aktif yang masuk ke dalam tubuh serangga tidak cukup untuk mempengaruhi syaraf pusat untuk memberi sinyal penghentian proses makan.

Penurunan laju pertumbuhan relatif menunjukkan adanya toksisitas intrinsik yang masuk ke dalam tubuh larva, mempengaruhi metabolisme tubuh larva $C$. pavonana dan berdampak pada pertumbuhannya. Meskipun pada konsentrasi rendah, bahan aktif yang masuk saat larva tetap

Tabel 3. Aktivitas enzim sitokrom b5 dan sitokrom P450 pada larva Crocidolomia pavonana

\begin{tabular}{lcccccc}
\hline Perlakuan & \multicolumn{2}{c}{ Aktivitas enzim $(\mu \mathrm{M})$} & \multicolumn{2}{c}{ Kadar protein $(\mathrm{mg} / \mathrm{ml})$} & \multicolumn{2}{c}{$\begin{array}{c}\text { Aktvitas spesifik } \\
\text { (nmol/mg protein) }\end{array}$} \\
\hline Sitokrom & $\mathrm{b} 5$ & $\mathrm{P} 450$ & $\mathrm{~b} 5$ & $\mathrm{P} 450$ & $\mathrm{~b} 5$ & $\mathrm{P} 450$ \\
\hline Kontrol & 0,011 & 0,055 & 4,61 & 4,61 & 0,047 & 0,238 \\
In vivo & 0,059 & 0,055 & 3,16 & 3,16 & 0,378 & 0,347 \\
In vitro & 0,25 & 0,197 & 5,37 & 5,37 & 0,931 & 0,736 \\
\hline
\end{tabular}


memakan daun perlakuan akan mencapai titik akumulasi toksik dan dapat menyebabkan kematian. Bahan aktif yang masuk kemungkinan besar rotenon dan senyawa rotenoid lain yang bersifat insektisida seperti deguelin dan tefrosin (Delfel et al. 1970; Gaskins et al. 1972; Lambert et al. 1993) yang berasal dari T. vogelii. Selain itu, bahan aktif yang terkandung dalam $P$. aduncum yang bersifat racun syaraf dan senyawa sinergis turut mengganggu aktivitas fisiologi serangga (Perry et al. 1998; Scoot et al. 2007). Penghambatan aktivitas enzim dan pengaruh bahan aktif yang bersifat insektisida dari kedua ekstrak mengganggu pertumbuhan relatif larva uji secara keseluruhan.

Efisiensi makanan yang dikonsumsi (EMK) dan efisiensi makanan yang dicerna (EMC) mengalami penurunan pada perlakuan $\mathrm{LC}_{50}$ meskipun hasil analisis statistika tidak menunjukkan perbedaan yang nyata dibandingkan dengan kontrol (Tabel 2). Hal menarik adalah daya cerna larva yang diberi perlakuan lebih tinggi dibandingkan dengan kontrol. Seperti yang dijelaskan oleh Schoonhoven et al. (2005) mekanisme untuk mengganti makanan suboptimal salah satunya adalah dengan meningkatkan daya cerna terhadap makanan dengan menyimpannya di dalam saluran pencernaan, hal ini dilakukan sebagai bentuk optimalisasi absorpsi nutrisi yang ada. Selain itu, serangga juga bisa mengambil strategi dengan meningkatkan laju konsumsi. Meningkatnya laju konsumsi, maka makanan harus segera diproses dan tidak bisa disimpan di pencernaan, akibatnya efisiensi makanan di konsumsi dan efisiensi makanan dicerna bisa mengalami penurunan. Stretegi $O$. nubilalis adalah dengan meningkatkan jumlah yang dimakan dan menurunkan laju efisiensi makanan yang dikonsumsi. Penelitian yang dilakukan Bernard et al. (1995) menunjukkan bahwa ekstrak kasar $P$. aduncum pada konsentrasi $0,4 \%$ dapat menghambat pertumbuhan $O$. nubilalis hingga lebih dari 80\%. Laju konsumsi larva (LK) tidak mengalami gangguan, menunjukkan penghambatan makan yang rendah bahkan cenderung meningkatkan konsumsi makan 3 sampai 8 kali lebih tinggi dibandingkan dengan kontrol. Daya cerna serangga juga tidak terlalu terpengaruh oleh alelokimia ekstrak, tetapi terjadi penurunan nilai EMC, menunjukkan adanya toksisitas komponen makanan yang di cerna.
Serangga juga dapat menggunakan beberapa strategi sekaligus, misalnya pada Anacridium melanorhodon (Walker) yang beradaptasi dengan keberadaan tannin di dalam makanan dengan meningkatkan pencernaan (DC) dan efisiensi makanan dikonsumsi (EMK).

Hasil aktivitas enzim sitokrom b5 dan sitokrom P450 menunjukkan respon serangga terhadap senyawa sekunder tanaman yang dideteksi sebagai senyawa asing. Sistem enzim segera menginduksi enzim detoksifikasi untuk menjalankan fungsinya. Serangga diketahui dapat melakukan metabolisme dan detoksifikasi senyawa sekunder dari famili Piperaceae dengan menginduksi enzim spesifik, yaitu famili Cyp 6 (Scott et al. 2005). Pengujian ekstrak etanol P. nigrum terhadap Drosophila melanogaster Meigen meningkatkan regulasi gen sitokrom P450 Cyp6a8, Cyp9b2, Cyp12d1, Cyp6d4, Cyp6d5 dan Cyp6wl bersamaan dengan gluthatione S-tranferase S1 dan glutathione S-transferase E7 (Jensen et al. 2006a).

Mekanisme enzimatis monooksigenase sitokrom P450 di dalam tubuh serangga diawali dengan adanya zat-zat asing yang bersifat lipofilik yang merupakan substrat bagi sitokrom P450. Dalam keadaan teroksidasi, sitokrom P450 berikatan dengan substrat. Sitokrom P450 kemudian berubah menjadi tereduksi dibantu oleh NADPHsitokrom-c-reduktase yang membantu transfer elektron NADPH ke sitokrom P450. Sitokrom P450 yang telah tereduksi akan mengikat molekul oksigen dan menghasilkan ion oksida yang sangat reaktif. Ion oksida tersebut bereaksi dengan proton membentuk air sedangkan oksigen bereaksi dengan substrat, sehingga substrat yang awalnya lipofilik menjadi bersifat hidrofilik. Substrat hidrofilik ini larut dengan air sehingga lebih mudah masuk ke dalam sistem sekresi serangga (Kranthi 2005). Sitokrom b5 dapat menggantikan enzim NADPHsitokrom-c-reduktase yang merubah sitokrom P450 teroksidasi menjadi tereduksi. Oleh karena itu, secara umum peningkatan sitokrom b5 sebanding dengan peningkatan sitokrom P450.

Efek penghambatan sitokrom b5 dan sitokrom P450 tidak tampak pada perlakuan in vivo dan in vitro. Hal ini disebabkan oleh, peningkatan regulasi gen Cyp konsisten dengan efek bifasik komponen yang mengandung metilen dioksifenil (MDP), penghambatan enzim Cyp diikuti dengan 
induksi enzim Cyp tersebut (Jensen et al. 2006a). Penghambatan terhadap gen yang diekspresikan kemudian ada kenaikan pada gen yang sama menunjukkan adanya stres dan respons spesifik terhadap toksin (Jensen et al. 2006b). Faktor lain yang juga berperan dalam hasil uji adalah tingkat kemurnian minyak $P$. aduncum yang digunakan. Bahan aktif dillapiol yang terkandung dalam minyak $P$. aduncum pada percobaan ini hanya sebesar $79,35 \%$. Selain dillapiol juga ditemukan senyawa lain yang ada pada minyak $P$. aduncum yang digunakan, yang diduga menginduksi gen enzim detoksifikasi.

Secara umum aktivitas enzim pada kontrol paling rendah, karena tidak ada senyawa asing yang ditemukan pada sampel maka aktivitas spesifik sitokrom b5 dan P450 tidak tinggi. Pada perlakuan in vivo, proses deteksi dan detoksifikasi terjadi secara alami di dalam tubuh serangga sehingga aktivitas sitokrom b5 dan sitokrom P450 menunjukkan aktivitas yang setara. Pada perlakuan in vitro, senyawa asing ditemukan dalam jumlah besar maka aktivitas kedua enzim secara keseluruhan lebih tinggi dan sitokrom b5 juga lebih tinggi dibandingkan dengan sitokrom P450.

\section{KESIMPULAN}

Ekstrak campuran T. vogelii : P. aduncum (1 : 5) memiliki efek antifeedant sekunder terhadap larva $C$. pavonana. Asimilasi makanan $C$. pavonana yang diberi perlakuan ekstrak campuran T. vogelii : P. aduncum $(1: 5)$ pada $\mathrm{LC}_{25}$ dan $\mathrm{LC}_{50}$ menyebabkan gangguan pertumbuhan relatif akibat toksisitas intrinsik ekstrak campuran yang masuk ke dalam tubuh serangga. Keberadaan senyawa asing meningkatkan daya cerna serangga sebagai bentuk adaptasi terhadap senyawa asing. Laju konsumsi makanan, efisiensi makanan di konsumsi dan efisiensi makanan dicerna tidak berbeda nyata jika dibandingkan dengan serangga yang tidak diberi perlakuan. Senyawa aktif pada P. aduncum menyebabkan aktivitas enzim oksidasi sitokrom b5 dan sitokrom P450 meningkat pada perlakuan in vivo dan in vitro jika dibandingkan dengan kontrol. Efek sinergis komponen utama $P$. aduncum (dilapiol) tidak tampak pada percobaan ini. Kemurnian senyawa merupakan salah satu faktor penyebab selain mekanisme kerja dilapiol yang mengalami induksi setelah terjadi penghambatan pada enzim detoksifikasi.

\section{DAFTAR PUSTAKA}

Abizar M, Prijono D. 2010. Aktivitas insektisida ekstrak daun dan biji Tephrosia vogelii J.D. Hooker (Leguminosae) dan ekstrak buah Piper cubeba L. (Piperaceae) terhadap larva Crocidolomia pavonana (F.) (Lepidoptera: Crambidae). Jurnal HPT Tropika 10:1-12.

Bernard CB, Arnason JT, Philogene BJR, Lam J, Waddell T. 1989. Effect of lignans and other secondary metabolites of the asteraceae on the mono-oxygenase activity of the European corn borer. Phytochemistry 28:1373-1377. doi: http:// dx.doi.org/10.1016/S0031-9422(00)97749-5.

Bernard CB, Krishnamurty HG, Chauret D, Durst T, Philogene BJR et al. 1995. Insecticidal defenses of Piperaceae from the Neotropics. Journal of Chemical Ecology 21:801-814. doi: http:// dx.doi.org/10.1007/BF02033462.

Bernard CB, Arnason JT, Philogène BJR, Lam J, Waddell T. 1990. In vivo effect of mixtures of allelochemicals on the life cycle of the European corn borer, Ostrinia nubilalis. Entomologia Experimentalis Et Applicata 57:17-22. doi: http://dx.doi.org/10.1111/j.1570-7458.1990. tb01411.x.

Delfel NE, Tallent WH, Carlson DG, Wolff IA. 1970. Distribution of rotenone and deguelin in Tephrosia vogelii and separation of rotenoidrich fractions. Journal of Agricultural and Food Chemistry 188:385-390. doi: http://dx.doi. org/10.1021/jf60169a053.

Dauterman WC, Hodgson E. 1978. Detoxication Mechanism in Insect. In: Rockstein M (Ed.), Biochemistry of Insect. pp. 541-577. London: Academic Press. doi: http://dx. doi.org/10.1016/ b978-0-12-591640-0.50018-2.

Flores N, Jimenez IA, Gimenez A, Ruiz G, Gutierez D, Bourdy G, Bazzocchi IL. 2009. Antiparasitic activity of prenylated benzoic acid derivatives from Piper species. Phytochemistry 70:621-627. doi: http://dx.doi.org/10.1016/j. phytochem.2009.03.010.

Fraenkel G. 1969. Evaluation of our thoughts on secondary plant substances. Entomologia Experimentalis et Applicata 12:473-486. doi: http://dx.doi.org/10.1111/j.1570-7458.1969. tb02546.x. 
Gaskins MH, White GA, Martin FW, Delfel NE, Ruppel EG, Barnes DK. 1972. Tephrosia vogelii: A Source of Rotenoids for Insecticidal and Piscicidal Use. Washington DC: United States Department of Agriculture.

Jensen HR, Scoot IM, Sims S, Trudeau VL, Arnason JT. 2006a. Gene expression profiles of Drosophila melanogaster exposed to an insecticidal extract of Piper nigrum. Journal of Agricultural and Food Chemistry 54:1289-1295. doi: http:// dx.doi.org/10.1021/jf052046n.

Jensen HR, Scott IM, Sims SR, Trudeau VL, Arnason JT. 2006b. The effect of a synergistic concentration of a piper nigrum extract used in conjunction with pyrethrum upon gene expression in Drosophila melanogaster. Insect Molecular Biology 15:329-339. doi: http:// dx.doi.org/10.1111/j.1365-2583.2006.00648.x.

Kranthi KR. 2005. Insecticide Resistance Monitoring, Mechanisms and Management Manual. No.2. Nagpur: Central Institute for Cotton Research.

Kogan M. 1982. Plant resistance in pest management. In: Metcalf RL, Luckman WH (Eds.), Introduction to Insect Pest Management. ${ }^{\text {nd }}$. pp. 93-134. New York: Jhon Willey \& Sons.

Lago JHG, Chen A, Young MCM, Guimaraes EF, Oliveira A de, Kato MJ. 2009. Prenylated benzoic acid derivatives from Piper aduncum L. and P. hostmannianum C. DC. (Piperaceae). Phytochem Lett 2:96-98. doi: http://dx.doi. org/10.1016/j.phytol.2009.01.001.

Lambert N, Trouslot MF, Campa CN, Chrestin H. 1993. Production of rotenoids by heterotrophic and photomixotrophic cell cultures of Tephrosia vogelii. Phytochemistry 34:1515-1520. doi: http:// dx.doi.org/10.1016/S0031-9422(00)90838-0.

Lina EC, Prijono D, Dadang. 2006. Physiological interferences in the soybean armyworms Spodoptera litura F. caused by active fractions of Aglaia harmsiana extract. Jurnal Tumbuhan Tropika 6:1-8.

Metcalf RL. 1967. Mode of action of insecticide synergists. Annual Review of Entomology 12:229256. doi: http://dx.doi.org/10.1146/annurev.en.12. 010167.001305 .
Miller JR, Stricler KL. 1984. Finding and accepting host plants. In: Bell WJ, Carde RT (Ed.), Chemical Ecology of Insect. pp. 127-157. Massachusetts: Sinauer, Sunderland. doi: http:// dx.doi.org/10.1007/978-1-4899-3368-3_6.

Morallo-Rejesus B. 1986. Botanical insecticides against the diamondback moth. Available at: http://www.avrdc.orgpdf86dbm86DBM23.pdf [16 Maret 2007].

Nailufar N. 2011. Aktivitas insektisida ekstrak daun Tephrosia vogelii (Leguminosae) dan buah Piper aduncum (Piperaceae) terhadap larva Crocidolomia pavonana. Skripsi. Bogor: Institut Pertanian Bogor.

Omura T, Sato R. 1964. The carbon monoxide-binding pigment of liver microsomes; solubilization, purification, and properties. The Journal of Biological Chemistry 239:2379-2385.

Perry AS, Yamamoto I, Ishaaya I, Perry RY. 1998. Insecticides in Agriculture and Environment: Retrospects and Prospects. Berlin: SpringerVerlag. doi: http://dx.doi.org/10.1007/978-3662-03656-3.

Schoonhoven LM, Van Loon JJA, Dicke M. 2005. Insect Plant Biology. London: Oxford University Press.

Scott IM, Jensen HR, Philogene BJR, Arnason JT. 2007. A review of Piper spp. (Piperaceae): phytochemistry, insecticidal activity, and mode of action. Phytochemistry Reviews 7:65-75. doi: http://dx.doi.org/10.1007/s11101-006-9058-5.

Steel RGD, Torrie JH, Dickey DA. 1997. Principles and Procedures of Statistics: A Biometrical Approach. $3^{\text {rd }}$ ed. Boston: McGraw-Hill.

Waldbauer GP. 1968. The consumption and utilization of food by insect. Advances in Insect Physiology 1:229-288. http://dx.doi.org/10.1016/S0065-28 06(08)60230-1.

Wulan RDR. 2008. Aktivitas Insektisida Ekstrak Daun Tephrosia vogelii Hook. f. (Leguminosae) terhadap Larva Crocidolomia pavonana (F.) (Lepidoptera: Pyralidae). Skripsi. Bogor: Institut Pertanian Bogor. 